\section{Correspondence to 'Normal human enthesis harbours conventional CD4+ and CD8+ T cells with regulatory features and inducible IL-17A and TNF expression'}

We read with great interest the work by Watad et al, ${ }^{1}$ which the authors demonstrated the characterisation of enthesisresident $\mathrm{T}$ cells and their corresponding cytokine responses upon stimulation. This commendable work mimicked enthesitis-involved inflammatory pathogenesis of spondyloarthritis, for instance, psoriatic arthritis (PsA). Particularly, the authors proposed that entheseal $\mathrm{T}$ cells may secrete interleukin (IL)-17 and much more tumour necrosis factor $\alpha$ (TNF- $\alpha$ ) in response to anti-CD3 and anti-CD28 (as suggested in figure 3 by Watad $e t \mathrm{al}^{1}$ ); furthermore, phosphodiesterase 4 (PDE4) inhibitors suppressed the expression of the above mentioned inflammatory cytokines (as suggested in figure 5 by Watad et $a l^{1}$ ). As PDE4 inhibitors have been used to treat autoimmune diseases and advanced malignancies, ${ }^{2}$ we are highly interested in whether infliximab, a neutralised antibody for TNF- $\alpha$ and a widely prescribed biologic disease-modifying antirheumatic drugs for a number of autoimmune diseases, would as well modulate the immunity of entheseal or synovial $\mathrm{T}$ cells in patients with PsA in clinical settings.

We compared the RNA-sequencing profiles of synovial biopsies from patients with PsA naive to anti-TNF- $\alpha$ agents before and 10 weeks after infliximab treatment registered in the National Center for Biotechnology Information-Gene Expression Omnibus database. Overall, we identified 39 significantly expressed pathways using $\mathrm{p}$ value and $\mathrm{Z}$-score visualisation, with 26 pathways up-regulated at a Z-score of above 1 , and 13 pathways down-regulated at a Z-score of less than -1 (figure 1). Among the 26 upregulated pathways after infliximab treatment, well-documented immunomodulatory signalling pathways, including adrenomedullin signalling pathway, ${ }^{3}$ transforming growth factor- $\beta$ (TGF- $\beta$ ) signalling and aryl

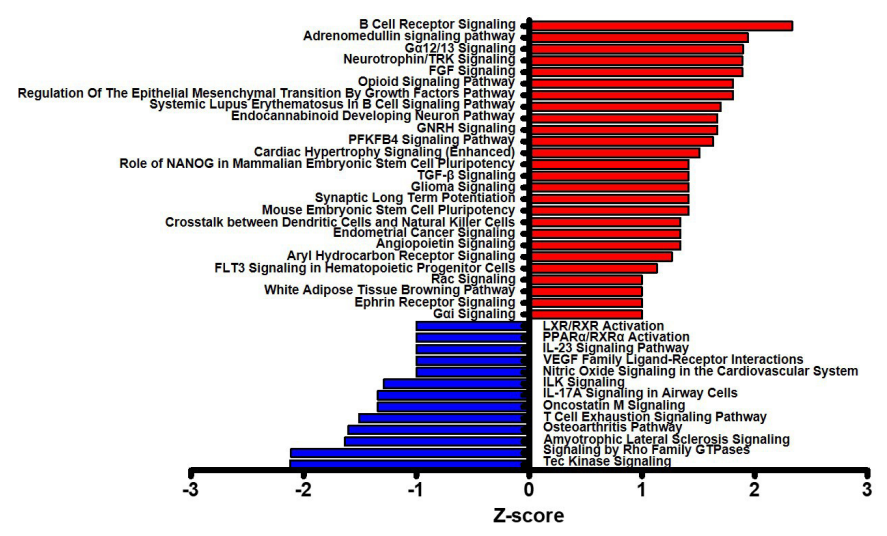

Figure 1 Canonical pathway analysis on RNA-seq data of synovial biopsy from patients with psoriatic arthritis receiving infliximab treatment after a follow-up of 10 weeks. Upregulated pathways are labelled in red. Downregulated pathways are labelled in blue. FGF, fibroblast growth factor; FLT3, FMS-like tyrosine kinase 3; GNRH, gonadotropin-releasing hormone; IL, interleukin; ILK, integrin-linked kinase; LXR, liver X receptor; NANOG, homeobox transcription factor Nanog; PFKB4, 6-phosphofructo-2-kinase/fructose-2,6-biphosphatase 4; PPAR $\alpha$, peroxisome proliferator-activated receptor $\alpha$; RXR, retinoid X receptor; TRK, tropomyosin receptor kinase; VEGF, vascular endothelial growth factor. hydrocarbon receptor signalling, were noted; furthermore, B cell-involved pathways, including B cell receptor signalling and systemic lupus erythematosus-associated B cell signalling pathway, were as well activated after TNF- $\alpha$ blockage. Among the 13 downregulated pathways after infliximab treatment, both Tec kinase signalling and signalling by Rho family GTPases were significantly inhibited at a Z-score of less than -2 . These findings are consistent with previous studies reporting that Tec kinases regulate signalling pathways downstream of T cell receptor (TCR) activation, followed by T cell development, cytokine production and T-helper cell differentiation. ${ }^{4}$ On the other hand, these findings are in line with the fact that Rho GTPases initiate signalling following TCR activation, which allow them to modulate pathways responsible for T cell development, differentiation and activation. ${ }^{5}$ Moreover, as IL-23 signalling, a pathway upstream of Th17 induction, ${ }^{6}$ was also downregulated after infliximab treatment, it was suggested that reciprocal regulation between TNF- $\alpha$ and IL-17 took place in synovial $\mathrm{T}$ cells during anti-TNF- $\alpha$ therapy. ${ }^{7}$

In conclusion, our data supported that the activity of entheseal and synovial $\mathrm{T}$ cells was suppressed in patients with PsA treated with TNF- $\alpha$ inhibitors, potently accompanying with an overall downregulation in pathways underlying the pathogenesis of PsA.

\section{Li-Tzu Wang, ${ }^{1}$ Kevin Sheng-Kai Ma $\odot^{2}$}

${ }^{1}$ Institute of Cellular and System Medicine, National Health Research Institutes, Miaoli, Taiwan, Republic of China

${ }^{2}$ Department of Life Science, National Taiwan University, Taipei, Taiwan, Republic of China

Correspondence to Dr Kevin Sheng-Kai Ma, National Taiwan University, Taipei, Republic of China; sheng.kai.ma@cern.ch

Contributors Both authors contributed equally to conceptualization, data analysis and discussion.

Funding The authors have not declared a specific grant for this research from any funding agency in the public, commercial or not-for-profit sectors.

Competing interests None declared.

Patient and public involvement Patients and/or the public were not involved in the design, or conduct, or reporting, or dissemination plans of this research.

Patient consent for publication Not required.

Provenance and peer review Not commissioned; internally peer reviewed. (C) Author(s) (or their employer(s)) 2020. No commercial re-use. See rights and permissions. Published by BMJ.

L-TW and KS-KM are joint first authors.

\section{Check for updates}

To cite Wang L-T, Ma KS-K. Ann Rheum Dis Epub ahead of print: [please include Day Month Year]. doi:10.1136/annrheumdis-2020-218995

Received 31 August 2020

Accepted 3 September 2020

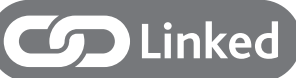

- http://dx.doi.org/10.1136/annrheumdis-2020-219047

Ann Rheum Dis 2020;0:1-2. doi:10.1136/annrheumdis-2020-218995

ORCID iD

Kevin Sheng-Kai Ma http://orcid.org/0000-0002-9394-4144

\section{REFERENCES}

1 Watad A, Rowe H, Russell T, et al. Normal human enthesis harbours conventional CD4+ and CD8+ T cells with regulatory features and inducible IL-17A and TNF expression. Ann Rheum Dis 2020;79:1044-54. 
2 Kelly K, Mejia A, Suhasini AN, et al. Safety and pharmacodynamics of the PDE4 inhibitor roflumilast in advanced B-cell malignancies. Clin Cancer Res 2017;23:1186-92.

3 Matson BC, Caron KM. Adrenomedullin and endocrine control of immune cells during pregnancy. Cell Mol Immunol 2014;11:456-9.

4 Lucas JA, Miller AT, Atherly LO, et al. The role of Tec family kinases in T cell development and function. Immunol Rev 2003;191:119-38.
5 Saoudi A, Kassem S, Dejean A, et al. Rho-GTPases as key regulators of T lymphocyte biology. Small GTPases 2014;5. doi:10.4161/sgtp.28208. [Epub ahead of print: 08 May 2014].

6 Gaffen SL, Jain R, Garg AV, et al. The IL-23-IL-17 immune axis: from mechanisms to therapeutic testing. Nat Rev Immunol 2014;14:585-600.

7 Hawkes JE, Chan TC, Krueger JG. Psoriasis pathogenesis and the development of novel targeted immune therapies. J Allergy Clin Immunol 2017;140:645-53. 